\title{
Teachers' Perceptions on Online Behaviour of Students with Intellectual Disability, Risk Mediation and Training
}

Marcos Gómez-Puerta ${ }^{\mathrm{a}} \&$ Esther Chiner ${ }^{\mathrm{b}}$

a Department of Developmental Psychology and Teaching, University of Alicante, Alicante, Spain. (D) http://orcid.org/0000-0003-0406-0214

${ }^{\mathrm{b}}$ Department of Health Psychology, University of Alicante, Alicante, Spain. http://orcid.org/0000-0002-1546-7071

Corresponding author:

Marcos Gómez-Puerta

Department of Developmental Psychology and Teaching University of Alicante

Carretera de San Vicente del Raspeig, s/n

CP 03690 San Vicente del Raspeig

Alicante (Spain)

marcos.gomez@ua.es

\section{Notes on contributors}

Marcos Gómez-Puerta is Lecturer of Teaching and School Organization at the University of Alicante, Spain. His research interests are related to inclusive education and digital inclusion of people with intellectual and developmental disabilities.

Esther Chiner is Senior Lecturer of Educational Research and Assessment at the University of Alicante, Spain. Her research interests are related to inclusive education and digital inclusion of people with intellectual and developmental disabilities.

\section{Word count (main manuscript): 7533 words.}




\title{
Teachers' Perceptions on Online Behaviour of Students with Intellectual Disability, Risk Mediation and Training
}

\begin{abstract}
The presence of the Internet in society has raised a growing interest in the potential benefits and risks of this tool and its consequences in certain groups like students with intellectual disabilities. The purpose of this study was to explore teachers' perceptions about the behaviours conducted by this population and the ability of these professionals to prevent and/or manage potential risks on the Internet for this group. A cross-sectional study was conducted based on a survey design in which 258 Spanish teachers participated. Descriptive and nonparametric analyses were performed to examine and compare teachers' responses. Findings indicate that, according to respondents, students with intellectual disabilities frequently connect to the Internet, mainly to watch videos or films, listen to music and socialize with friends. They also reveal the presence of unwanted online behaviours that this group has experienced or engaged in. Teachers report they are not sufficiently prepared or have received the necessary training to prevent and/or manage these risks. However, they have put into practice active mediation strategies to prevent them. Significant differences were found in teachers' perceptions based on teaching level and teaching position. The need to implement training plans is recommended.
\end{abstract}

Keywords: intellectual disability; Internet; online behaviour; mediation; training; teachers

\section{Introduction}

Inclusion is the right of persons with disabilities to participate fully in educational, employment, consumption, recreational, community and domestic activities corresponding to the ordinary life of their fellow citizens (Inclusion International 1996). The participation of people with disabilities in our information and communication society necessarily involves the access and use of the Internet. However, a digital divide has been observed 
derived from the difficulty of certain groups to use digital devices and access to the Internet. Among the groups affected by this gap, are people with intellectual disabilities (ID) (Valero et al. 2011). In this regard, the United Nations (2006) already highlighted the importance of promoting the access of people with disabilities to information and communication systems and technologies such as the Internet.

Access to the Internet implies both benefits and risks for its users. In the European context, the EU Kids Online study found that minors are exposed to risks such as cyberbullying, access to pornography, contact with strangers or receiving unwanted sexual messages or sexting (Livingstone et al. 2011). This fact highlighted the urgency of investigating specific risks for other groups susceptible to abuse. Among them are people with ID, whose social behaviour shows a tendency to ingenuity and credulity (Luckasson et al. 2002). In this sense, research on Internet and ID has focused on analyzing, on the one hand, the use of the Internet and online behaviour and, on the other, the benefits and risks that this involves (Chadwick, Quinn, and Fullwood 2017). Although they are still scarce, the most relevant studies to date point to some noteworthy data.

Regarding the use of the Internet by people with ID, the data show that they use digital devices less than people without ID (Chadwick, Wesson, and Fullwood 2013), although they have attitudes prone to this behaviour (Fundación Auna 2004). The study by Gutiérrez and Martorell (2011), carried out in Spain with 156 people with ID from a specialized association, indicated that $41.7 \%$ lacked Internet access from any device, whereas only $50 \%$ of the participants had Internet access at home. Despite the fact that $89.7 \%$ claimed they had a mobile phone, only $6.4 \%$ admitted using Internet connections outside the home. In this regard, possible limitations to the use of the Internet are the 
prejudices of the social environment around these persons. Prejudices are the ideas present in the context of the individuals about their abilities, which can be harmful when they become psychological barriers that hinder their development. This tendency manifests itself especially when one considers that the benefits are fewer than the risks (Lough and Fisher 2016), favouring infantilisation and overprotection towards these groups. Therefore, it is key to identify such prejudices, primarily those of people close to the person with ID (Seale and Chadwick 2017) in order to implement strategies (e.g. training, information) that limit or eliminate these prejudices (Morin et al. 2013). The available evidence shows that carers (e.g. teachers, support workers) monitor Internet access if they perceive that people with ID will find risks that they will not be able to handle (Seale 2014). This control occurs in two ways. First, carers limit or reduce access to the Internet (Chadwick and Wesson 2016) and, second, they control and even censor the online content they can access (Seale and Chadwick 2017). This tendency is relevant because people without disabilities tend to think, on the one hand, that online benefits and risks are greater for people with ID than without ID (Chadwick, Quinn, and Fullwood 2017) and, on the other, that the Internet is an unsafe environment for children and young people with ID (Chiner, Gómez-Puerta, and Cardona-Moltó 2017a).

In contrast to the above mentioned studies, it has become clear that carers are not only the primary source of support for the use of technology by students with ID (Palmer et al. 2012) but also they are an effective resource for the prevention of cybervictimisation of these persons (Wright 2017). However, in addition to the possible presence of prejudices, carers show certain limitations that should be considered. First, a study conducted in Spain that included 77 adults with ID and 68 family members (Chiner, Gómez-Puerta, and 
Cardona-Moltó 2017b) demonstrated that there were discrepancies between the risks experienced and inappropriate actions that people with ID reported they had carried out online, compared to those that their family members stated that they were aware of. In terms of risks, $39 \%$ of the family members indicated they were totally unaware of them. On the other hand, family members tended to perceive more online problems with regard to their children with ID than the people with ID themselves acknowledged, although the responses of people with ID may be biased by social desirability. Secondly, Normand and Sallfranque-St-Louis (2016) indicated, first, that the phenomenon of online risks for people with ID is still little known scientifically and in an exploratory phase and, secondly, more training and support is needed for the carers to be able to manage the risks involved. Finally, in the third place, various authors have highlighted the importance that the training for carers could have in the approach of mediation as an online risk prevention and management strategy (Kalmus, von Feilitzen, and Siibak 2012; Karaseva, Siibak, and Pruulmann-Vengerfeldt 2015). Mediation consists of a set of strategies that are socially modulated and that aim to interact between two parties (Kalmus 2013). Internet mediation strategies can be grouped into four categories (Livingstone et al. 2011): active mediation (e.g. sitting with them while using the internet), restrictive mediation (e.g. forbidding certain uses of the Internet), monitoring mediation (e.g. checking browser history) and technical mediation (e.g. installing filters that block certain web pages). Concerning mediation, the perspective of positive risk management (Seale, Nind, and Simmons 2013) underlines the importance of enabling people with ID to exercise greater control over their lives, with supports necessary for the identification and management of risks both proactively and reactively (Molin, Sorbring, and Löfgren-Martenson 2015). In this regard, 
instead of ignoring or avoiding such risks, people with ID and their carers should address them and make negotiated and consensual decisions about them (McConkey and Smyth 2003).

The study of teachers' beliefs is a line of research widely developed in the field of Educational Sciences (Fang 1996; Fives and Gill 2015; Munby 1982). However, the issue of teachers' beliefs about students with ID is still insufficiently described in the scientific literature. A clearly identified aspect is that the teaching staff tends to show attitudes less prone to inclusion over those students whose disability is perceived as more severe, which is the case of students with ID (Avramidis and Norwich 2002). Therefore, teachers can develop less favourable behaviours and prejudices towards the teaching of skills that favour their personal autonomy or inclusion since they consider that students with ID will not achieve it, thus generating a vicious circle that prevents their development by not training their skills (O’Brien 1985). This overprotective attitude limits the stimulation and development of the student's potential and, in particular, hinders the ability and provision of supports for digital inclusion, issues that have been shown essential to facilitate their access to the Internet (Kydland, Molka-Danielsen, and Balandin 2012; Näslund and Gardelli 2013).

Given the scarce international and local knowledge of online risks for people with ID, the present study aims to expand the exploratory perspective of this phenomenon. Specifically, it attempts to complement the research by Chiner et al. (2017b) focusing on teachers' perceptions and expand on the study from a local level (a specialized association) to a larger population (schools of the Valencian Community, Spain). Thus, the purpose of this research is to know patterns of use and online behaviour of students with ID according 
to the information provided by teachers. Moreover, it aims to identify the risk mediation strategies implemented by them, as well as their training needs in order to prevent and/or manage negative online experiences for students with ID. Differences in teachers' responses based on teaching level (primary and secondary education) and teaching position (general and special education) were also addressed.

\section{Material and Methods}

\section{Participants}

Stratified cluster sampling was carried out taking the three provinces of the Valencian Community, Spain, as stratum to randomly select the schools $(N=138)$. Once selected, the collaboration of six teachers from each school was requested. A sample of 258 participants from 49 schools was obtained, composed of 171 (66.3\%) primary education teachers and $87(33.7 \%)$ secondary education teachers. Attending to their teaching position, $144(55.8 \%)$ were general education teachers and $114(44.2 \%)$ were special education teachers. Regarding the characteristics of the sample, 71 were males (27.5\%) and 187 females (72.5\%) with a mean age of $44.19(S D=10.09)$. Their work experience was 17.18 years $(S D=9.55)$ and most teachers had taught students with mild or moderate ID in the previous five years $(n=217,84.1 \%)$.

\section{Materials}

A questionnaire was designed using the work developed by the European network EU Kids Online (Livingstone et al. 2011) as a framework and adapting its content to the characteristics of the target research population. 
With regard to the use and behaviours on the Internet of students with ID, the questionnaire included a closed response item on the frequency of Internet use, a list of 13 online activities from which participants had to choose the five most frequent, and a list of 15 online behaviours considered inappropriate. Respondents had to answer if students with ID had ever encountered the behaviour and/or had carried it out or if, on the contrary, they had no knowledge. To avoid the variability in the answers depending on the characteristics of the students with ID, the respondents only considered students who had a mild or moderate ID.

Regarding mediation strategies, two items were included on a 5-point Likert scale (1=not at all prepared, 5=very prepared $)$ on the perceived level of preparation of teachers to prevent and manage online risks. It also included a list of 25 Internet mediation strategies potentially promoted by the schools and the teachers.

Finally, respondents were asked about the training received on Internet use and safety. They also had to mark, among a list of 9 items, the sources from which they had obtained information/training on online safety and those from which they would like to obtain it (e.g. workplace, Public Administration).

The questionnaire was previously reviewed by 10 experts in education and ICT, obtaining a content validity index of .87 (Lawshe 1975). The reliability was adequate, with alpha values higher than .81 in each of the parts of the questionnaire.

\section{Procedure}

A cross-sectional design was carried out, with the approval of the Ethics Committee of the university of the research team (procedure UA-2017-11-15) and with the informed consent 
of the participants. The surveys were anonymised and sent by post to the selected schools, including a postage-paid envelope for their return and a cover letter. They were asked to return the completed questionnaires within a month. In addition, an email was sent to the schools informing them about the mailing and the purpose of the study, as well as a followup email two weeks later. The time required to respond to the instrument was 10-15 minutes.

Of the 138 schools to which the questionnaire was sent, $49(35.5 \%)$ returned it completed and the final sample $(n=258)$ represented a response rate of $31.15 \%$. A wave analysis was conducted to check whether participants' responses were biased due to low return rate, concluding that their answers were similar (Creswell 2012).

Descriptive statistics were calculated. For the comparison of groups, the Pearson's chi-square test was used for dichotomous variables and the Mann-Whitney U test was used for Likert scale questions. The Cochran's Q and McNemar's tests, were used to compare the participants' knowledge on online behaviours experienced and engaged in by students with ID, as well as their responses on sources of information about Internet safety received or wanted.

\section{Results}

\section{Internet Use by students with Intellectual Disabilities}

The answers presented in this section refer to 216 teachers since one teacher reported to be unaware of the online activities carried out by his or her students with ID.

According to teachers' perceptions, students with ID connect to the Internet a maximum of three hours a day $(n=177,81.9 \%), 15.7 \%$ indicated they do so between four 
and five hours $(n=34)$ and $2.3 \%(n=5)$ considered that they access more than six hours a day. No statistically significant differences were found in teachers' responses based on teaching level and teaching position $(p>.05)$.

Regarding the type of online activities carried out by students with ID, the vast majority of respondents stated that they do so to watch videos, films or television $(n=201$, $93.1 \%)$, listen to music ( $n=170,78.7 \%)$, chat with friends $(n=158,73.1 \%)$, play online games $(n=152,70.4 \%)$, participate in social networks $(n=128,59.3 \%)$ and consult websites $(n=113,52.3 \%)$. To a lesser extent, respondents stated that students with ID use the Internet to chat with people met online $(n=42,19.4 \%)$, flirt $(n=37,17.1 \%)$ and write e-mails $(n=30$, $13.9 \%$ ), and very few participant teachers considered that students gain online access to read $(n=18,8.3 \%)$, gamble $(n=6,2.8 \%)$ and shop online $(n=5,2.3 \%)$. Differences were found concerning the activity 'writing e-mails', for which general education teachers reported a greater use $(19.2 \%)$ than special education teachers $\left(8.9 \%, \chi^{2}=3.963, p=.047\right)$, as well as secondary education teachers $(25.8 \%)$ when compared with primary education teachers $\left(8.7 \%, \chi^{2}=9.811, p=.002\right)$. Regarding the activity 'chatting with friends', secondary education teachers reported a greater use $(83.3 \%)$ than primary education teachers $\left(68.7 \%, \chi^{2}=4.301, p=.038\right)$.

\section{Online Behaviours Experienced and/or Engaged in by students with Intellectual}

\section{Disabilities}

Overall, teachers were unaware of potentially problematic online behaviours carried out or experienced by students with ID (Table 1). A high percentage of respondents did not know if students with ID had been involved in the illegal access to Internet accounts (77.5\%), in 
sending or receiving inappropriate material related to drugs $(77.5 \%)$ or with violent content $(72.5 \%)$, in frauds or scams $(75.6 \%)$ or in sexual harassment or grooming $(73.3 \%)$, among others.

Special education teachers were more unaware than general education teachers of most of the online behaviours experienced or carried out by students with ID: contact by/with strangers $\left(59.6 \%\right.$ vs $\left.41.7 \%, \chi^{2}=7.527, p=.006\right)$, sending/receiving material about drugs $\left(87.7 \%\right.$ vs $\left.69.4 \%, \chi^{2}=11.168, p=.001\right)$, sending/receiving material encouraging antisocial behaviour $\left(78.9 \%\right.$ vs $\left.62.5 \%, \chi^{2}=7.399, p=.007\right)$, in person meetings with people met online $\left(78.1 \%\right.$ vs $\left.56.3 \%, \chi^{2}=12.526, p=.000\right)$, frauds or scams $(86.8 \%$ vs $\left.66.7 \%, \chi^{2}=12.961, p=.000\right)$, grooming $\left(84.2 \%\right.$ vs $\left.64.6 \%, \chi^{2}=11.529, p=.001\right)$, participating in online gambling $\left(86.8 \%\right.$ vs $\left.69.4 \%, \chi^{2}=9.954, p=.002\right)$, illegal downloads $\left(75.4 \%\right.$ vs $\left.52.8 \%, \chi^{2}=13.032, p=.000\right)$, misuse of personal data $\left(71.9 \%\right.$ vs $56.9 \%, \chi^{2}=$ $5.539, p=.019)$, and illegal access to online accounts $\left(89.5 \%\right.$ vs $68.1 \%, \chi^{2}=15.543, p=$ .000). Likewise, primary education teachers reported to be more unaware than secondary education teachers of four online behaviours: contact by/with strangers $(56.1 \%$ vs $36.8 \%$, $\left.\chi^{2}=7.887, p=.005\right)$, grooming $\left(77.8 \%\right.$ vs $\left.64.4 \%, \chi^{2}=4.630, p=.031\right)$, illegal downloads $\left(67.8 \%\right.$ vs $\left.52.9 \%, \chi^{2}=4.904, p=.027\right)$, and misuse of personal data $\left(68.4 \%\right.$ vs $54 \%, \chi^{2}=$ $4.558, p=.033)$.

Regarding the possibility that students with ID had encountered some of the behaviours, respondents claimed to have proof of situations of bullying $(27.1 \%)$, threats (23.6\%), contact by strangers $(20.9 \%)$, or requests for personal information $(19.8 \%)$. They also highlighted the exposure to pornographic content $(14.7 \%)$, requests for in-person meetings with people met online $(10.9 \%)$, sexual harassment $(8.5 \%)$ and misuse of their 
personal data $(8.5 \%)$. Chi-square tests indicated differences between general education teachers and special education teachers, respectively, for behaviours such as bullying (16\% vs $\left.41.2 \%, \chi^{2}=19.271, p=.000\right)$, receiving pornographic content $\left(7.6 \%\right.$ vs $23.7 \%, \chi^{2}=$ $11.797, p=.001)$, being threatened $\left(16.7 \%\right.$ vs $\left.32.5 \%, \chi^{2}=7.934, p=.005\right)$, and receiving violent content $\left(3.5 \%\right.$ vs $\left.10.5 \%, \chi^{2}=4.062, p=.044\right)$. No significant differences were found concerning teaching level $(p>.05)$.

With regard to behaviours perpetrated by students with ID, highlighted again are bullying $(15.1 \%)$, threatening $(15.9 \%)$, contact with strangers $(20.5 \%)$, illegal downloads (15.9\%), asking for personal information (15.9\%), misuse of personal data $(12.4 \%)$ and sending pornographic content (12\%). Comparing groups, special education teachers reported more frequently than general education teachers the engagement by students with ID in behaviours such as bullying $\left(25.4 \%\right.$ vs $\left.6.9 \%, \chi^{2}=15.550, p=.000\right)$, sending pornographic content $\left(21.9 \%\right.$ vs $\left.4.2 \%, \chi^{2}=17.348, p=.000\right)$, threatening $\left(24.6 \%\right.$ vs $9 \%, \chi^{2}$ $=10.354, p=.001)$, and sending violent or gore content $\left(12.3 \%\right.$ vs $0.7 \%, \chi^{2}=13.554, p=$ .000). Likewise, primary education teachers referred more frequently than secondary education teachers the engagement by student with ID in behaviours such as bullying $\left(18.7 \%\right.$ vs $\left.8 \%, \chi^{2}=4.316, p=.038\right)$, threatening $\left(19.9 \%\right.$ vs $\left.8 \%, \chi^{2}=5.192, p=.023\right)$, and sending violent content $\left(8.2 \%\right.$ vs $\left.1.1 \%, \chi^{2}=4.010, p=.045\right)$.

\section{[Table 1 near here]}

\section{Preparation and Training Received on Internet Use and Safety}

The training received was practically non-existent, with $92.6 \%$ of the respondents reporting that they had not attended any course related to Internet use and safety. Furthermore, on a 
5-point Likert scale (1=not at all prepared, 5=very prepared), the perceived level of preparedness to prevent and manage risks on the Internet was low with an average of 2.88 $(S D=0.91)$ in risk prevention and $2.73(S D=0.90)$ in the management of online problems. Only $26.7 \%$ of the respondents revealed that they were prepared to prevent risks and $20.6 \%$ to manage them, while $35.6 \%$ and $41.9 \%$, respectively, indicated that they were very poorly prepared. Concerning teaching level, $39 \%$ of secondary education teachers felt prepared to prevent online risks compared with $20.5 \%$ of primary education teachers $(U=8561.5, z=$ 2.251, $p=.024)$. Similarly, $21 \%$ of secondary teachers felt prepared to address them compared with $15.2 \%$ of primary education teachers $(U=8555, z=2.079, p=.038)$. No statistically significant differences were observed with regard to teaching position $(p>.05)$.

Highlighted among the information sources on Internet use and online safety were the media (41.1\%), family and friends $(28.7 \%)$, workplace $(38 \%)$, and the Training and Resource Centres for Teachers (CEFIRE) (24\%) (Table 2). General education teachers received more information from their own workplace $\left(45.1 \%\right.$ vs $28.9 \%, \chi^{2}=.6 .411, p=$ $.011)$ and from the Public Administration $\left(25 \%\right.$ vs $\left.13.2 \%, \chi^{2}=4.904, p=.027\right)$ than special education teachers. Moreover, secondary education teachers received more information from the Public Administration (27.6\% vs $\left.15.8 \%, \chi^{2}=4.343, p=.037\right)$, specialized websites $\left(32.2 \%\right.$ vs $\left.17.5 \%, \chi^{2}=6.277, p=.012\right)$, and other sources $\left(13.8 \%\right.$ vs $4.1 \%, \chi^{2}=$ $6.594, p=.010)$ than primary education teachers.

Regarding information sources prioritized by the respondents, the workplace (38.8\%), the Training and Resource Centres for Teaching (CEFIRE) (53.9\%) and the Public Administration (40.3\%) stood out (Table 2). Differences were found between general and special education teachers, respectively, concerning the workplace as a 
preferred source of information $\left(31.3 \%\right.$, vs $\left.48.2 \%, \chi^{2}=7.043, p=.008\right)$ and the CEFIRE $\left(47.9 \%\right.$ vs $\left.61.4 \%, \chi^{2}=4.131, p=.031\right)$. Primary education teachers preferred more than secondary teachers information from the Public Administration $\left(45 \%\right.$ vs $31 \%, \chi^{2}=4.130, p$ $=.042)$ while the latter prioritized other sources more than primary teachers $(8 \%$ vs $1.8 \%$, $\left.\chi^{2}=4.554, p=.033\right)$.

The preference for the CEFIRE $\left(53.9 \%\right.$ vs $\left.24 \%, \chi^{2}=30.561, p=.000\right)$, the Internet service providers $\left(22.5 \%\right.$ vs $\left.4.3 \%, \chi^{2}=30.667, p=.000\right)$, and the Public Administration $\left(40.3 \%\right.$ vs $\left.19.8 \%, \chi^{2}=18.395, p=.000\right)$ as sources of information was significantly higher compared to the information or training received from them. On the contrary, respondents indicated receiving information from the media $\left(41.1 \%\right.$ vs $\left.16.3 \%, \chi^{2}=27.562, p=.000\right)$ and their family and friends $\left(28.7 \%\right.$ vs $\left.9.3 \%, \chi^{2}=24.500, p=.000\right)$ to a greater extent than they actually would have liked to.

\section{[Table 2 near here]}

\section{Online Risk Mediation Strategies}

Table 3 shows how the most frequent mediation strategies implemented in their schools or with family members are based on talking to students with ID about what they do on the Internet (84\%), about the risks of dating online with strangers (64.5\%), about which websites are appropriate or not (54.7\%), and about misleading advertising and the dangers of data or identity theft on the Internet $(56.5 \%)$. Likewise, respondents use other strategies such as staying close to them when they use the Internet (67.2\%), sharing activities online (62.5\%), activating content control filters (52.3\%) or installing antivirus or anti-spam programs $(46.9 \%)$. 
Special education teachers implemented more frequently than general education teachers strategies such as informative talks aimed at students with ID $\left(46 \%\right.$ vs $31.5 \%, \chi^{2}=$ $5.076, p=0.024)$, sit next to them $\left(60.2 \%\right.$ vs $\left.38.5 \%, \chi^{2}=11.070, p=0.001\right)$, stay close while using the Internet $\left(78.8 \%\right.$ vs $\left.58 \%, \chi^{2}=11.369, p=0.001\right)$, share online activities $\left(71.7 \%\right.$ vs $\left.55.2 \%, \chi^{2}=11.369, p=0.010\right)$, prohibit student from sharing personal information $\left(28.3 \%\right.$ vs $\left.16.8 \%,\left.\chi\right|^{2}=4.263, p=0.039\right)$. The organization of informative talks aimed at families $\left(62.9 \%\right.$ vs $\left.36.3 \%, \chi^{2}=16.896, p=0.000\right)$ and installing navigation and access control programs $\left(49.7 \%\right.$ vs $\left.27.4, \chi^{2}=12.088, p=0.001\right)$ were more frequently used by general education teachers than by special education teachers.

Regarding the teaching level, primary education teachers reported to sit next to the student when being online more frequently than secondary education teachers $(52.9 \%$ vs $38.4 \%, \chi^{2}=4.290, p=0.038$ ), while installing navigation and access control programs $\left(55.8 \%\right.$ vs $\left.31.8 \%, \chi^{2}=12.796, p=0.000\right)$ and talking to the students about the risks of data or identity theft $\left(72.1 \%\right.$ vs $\left.48.5 \%, \chi^{2}=11.943, p=0.001\right)$ were used more often by the latter.

\section{[Table 3 near here]}

\section{Discussion}

The aim of this study was, first, to know teachers' perceptions about the patterns of Internet use and online behaviour of students with ID and, secondly, to identify the risk mediation strategies implemented by the teaching staff, as well as the training received and wanted in order to put them into practice. The study also addressed the differences between the perceptions of general education and special education teachers, and between primary and 
secondary education teachers. Regarding Internet use, respondents considered that it was mainly recreational and leisure (e.g. watch videos, listen to music, play online), for which teachers perceived it was used on average of two to three hours a day. This perception is consistent with findings already presented by Chiner et al. (2017b) and Jenaro et al. (2018). A significant fact is that general education teachers perceive that their students with ID tend to use Internet to write emails more frequently than those reported by special education teachers. This trend can be related to the level of literacy skills of the students they teach, as it is very likely that special education teachers work with students with ID which present lower writing and reading skills. Similarly, secondary school teachers perceive that their students with ID use email and chats more than primary school teachers. This perception could be related, on the one hand, to the level of literacy competence and, on the other, to a greater social interest of puberty and adolescence.

Another noteworthy aspect was the lack of knowledge that respondents had about potentially problematic online behaviours experienced or performed by students with ID, a trend that had also been previously identified in other studies (Chiner, Gómez-Puerta, and Cardona-Moltó 2017b). This information is key because ignorance prevents selecting and implementing both prevention strategies and effective risk management once they appear (Seale, Nind, and Simmons 2013). Special education teachers expressed a greater unawareness of the behaviours carried out or experienced online by students with ID. A possible interpretation of this fact is related to teachers' prejudices. These teachers may perceive that their students have less skills to access and use Internet functionally, so teachers may collect less information about what their students with ID do online or what difficulties they encounter or cause. In this regard, the collaboration between families and 
teaching staff would be key to identify patterns of problematic behaviours and thus design prevention strategies and/or begin early intervention for behaviour problems, always in a negotiated manner with those involved (McConkey and Smyth 2003). Likewise, the comparison between primary and secondary teachers indicates that there are no significant differences in their perceptions regarding the online risks suffered by their students with ID. This view is paradoxical, especially when secondary education students are more likely to use the Internet than primary education students. Therefore, it would be advisable to deepen this issue in future studies.

Focusing on the respondents who claimed to be aware of problematic behaviours, these reported that among those behaviours encountered by students with ID more frequently were online bullying, threats or contact with strangers; while, among those behaviours engaged in by students with ID, were online bullying, threats, sending unwanted pornographic images or illegal downloads. These data are consistent with those already obtained in other studies (Didden et al. 2009; Jenaro, Flores, Vega, et al. 2018; Plichta 2015). In this regard, it seems that special education teachers are less aware of the situations experienced or carried out by their students with ID. However, when special education teachers and primary education teachers are aware of online problems, they report to a greater extent than general education teachers and secondary education teachers problems related to experiencing or perpetrating bullying, sending or receiving unwanted pornographic images, threatening or being threatened, and sending or receiving unwanted violent content. These differences may be related to the fact that families inform teachers of these incidents due to its gravity, while other online problems perceived as less important may not be communicated. In this sense, it is key that both teachers and families are aware 
of what are the online risks to prevent them as far as possible or, where appropriate, identify them as soon as possible to intervene on them. Concerning this, knowing and analyzing previously the perceptions of caregivers on Internet risks and benefits is considered the basis for later training on mediation strategies, as other authors have already highlighted (Karaseva, Siibak, and Pruulmann-Vengerfeldt 2015).

The observation of problematic behaviours both experienced and carried out underlines the importance of knowing in depth this phenomenon in order to respond to it adequately (Sallafranque-St-Louis and Normand 2017). However, the respondents in the study revealed a very low level of training on the subject received mainly from non-formal sources (media, family and friends). This fact highlights the need to initiate specific training in online risk mediation (Kalmus, von Feilitzen, and Siibak 2012), which should preferably be carried out through programmes developed by the Training and Resource Centres for Teaching, taking into account the priority of training sources stated by the respondents. This need for training is especially relevant in the case of special education teachers and primary education teachers, who reported that they have received significantly less information and training than general education teachers.

In terms of mediation strategies implemented by teachers mainly during formal class time, special education teachers indicated that they implemented a greater number of them than general education teachers. Despite the greater unawareness of the online behaviours of their students, special education teachers may implement more risk intervention strategies aimed at students in response to the seriousness of the online behaviours of which they are aware. On the contrary, general education teachers implement more actions aimed at families than their counterparts of special education. As for the type 
of actions implemented, teachers reported mainly active mediation strategies based on offering information about risks. These strategies seem to favour the student to understand the risks to which he/she is exposed online. Likewise, the respondents indicated that they also use monitoring, restriction or technical control strategies (e.g. staying close to them when using the Internet, sharing activities online). These strategies seem to reflect the need of teachers to exercise greater control over the individual's online behaviours, probably due to a lack of confidence in the student's ability to avoid the risks on his/her own or due to the school policy to control Internet access and use by students to avoid the appearance of problems online. Meanwhile, primary education teachers use more active mediation strategies such as sitting nearby while using the Internet, while in secondary school teachers combine active mediation (i.e. talking about risks of data or identity theft) and technical mediation (i.e. installing navigation and software for access control). Meanwhile, primary school teachers use more active mediation strategies such as sitting nearby while using the Internet, while in secondary school teachers combine active mediation (i.e. talking about risks of data or identity theft) and technical mediation (i.e. installing navigation and software for access control). One possible explanation for these differences is that in secondary education it is less appropriate for teachers to exercise face-to-face control of the student's behaviour since it could be childish, but it can be done indirectly through lectures or software to prevent the risks to which they can be exposed.

In sum, the findings showed first a lack of knowledge of potentially problematic online behaviour and, also, the presence of potentially problematic behaviours linked to a low level of preparation of teachers needed for effective Internet risk management. All this 
substantiates the importance of implementing training actions to improve their mediation skills.

This study presents several limitations to consider when interpreting its results. First, the sample is not representative of the population of teachers. Furthermore, the data shows exclusively the respondents' perceptions, which may not coincide fully with the objective reality of online behaviours experienced or engaged in by students with ID, or even on their true competence level for online risk management. Finally, the method used to collect data (postal survey) has certain limitations in itself (Creswell 2012). On the one hand, the researcher cannot clarify doubts in the interpretation of the questionnaire which can distort the answers due to a poor understanding of the questions, and on the other, this technique can cause a low response rate, increasing the possibility of bias in the data due to low representativeness.

In view of the relative novelty and relevance of the phenomenon, the educational and research implications of this study point to the need to explore in greater scope and depth teachers' capacity of risk management and mediation. Moreover, it is worthwhile to design, implement and measure the effectiveness of training plans for this professional group.

\section{Acknowledgments}

Researchers would like to thank participants for their generous contribution to this study.

\section{Declaration of interest statement}

The authors reported no potential conflict of interest. 


\section{Funding}

This work was supported by the Government of the Valencian Community (Spain) under Grant No GV/2017/006.

\section{References}

Avramidis, E., and B. Norwich. 2002. “Teachers” Attitudes towards Integration / Inclusion: A Review of the Literature". European Journal of Special Needs Education 17 (2): 129-47. doi: 10.1080/08856250210129056.

Chadwick, D., S. Quinn, and C. Fullwood. 2017. "Perceptions of the Risks and Benefits of Internet Access and Use by People with Intellectual Disabilities". British Journal of Learning Disabilities 45 (1): 21-31. doi: 10.1111/bld.12170.

Chadwick, D., and C. Wesson. 2016. "Digital Inclusion and Disability". In Applied Cyberpsychology, edited by A. Atrill and C. Fullwood, 1-24. Houndmills, UK: Palgrave Macmillan. doi: 10.1057/9781137517036_1.

Chadwick, D., C. Wesson, and C. Fullwood. 2013. "Internet Access by People with Intellectual Disabilities: Inequalities and Opportunities". Future Internet 5: 376-97. doi: 10.3390/fi5030376.

Chiner, E., M. Gómez-Puerta, and M. C. Cardona-Moltó. 2017a. "Internet and People with Intellectual Disability: An Approach to Caregivers' Concerns, Prevention Strategies and Training Needs". Journal of New Approaches in Educational Research 6 (2): 153158. doi: 10.7821/naer.2017.7.243. 
Chiner, E., M. Gómez-Puerta, and M. C. Cardona-Moltó. 2017b. "Internet Use, Risks and Online Behaviour: The View of Internet Users with Intellectual Disabilities and Their Caregivers”. British Journal of Learning Disabilities 45 (3). doi: 10.1111/bld.12192.

Creswell, J. W. 2012. Educational Research. Planning, Conducting, and Evaluating Quantitative and Qualitative Research. Boston: Pearson.

Didden, R., R. H. J. Scholte, H. Korzilius, J. M. H. De Moor, A. Vermeulen, M. O’Reilly, R. Lang, and G. E. Lancioni. 2009. “Cyberbullying among Students with Intellectual and Developmental Disability in Special Education Settings". Developmental Neurorehabilitation 12 (3): 146-51. doi: 10.1080/17518420902971356.

Fang, Z. 1996. "A Review of Research on Teacher Beliefs and Practices". Educational Research 38 (1): 47-65. doi: 10.1080/0013188960380104.

Fives, H., and M. G. Gill. 2015. International Handbook of Research on Teachers' Beliefs. New York: Routledge.

Fundación Auna. 2004. "Las personas con discapacidad frente a las tecnologías de la información y las comunicaciones en España" [People with Disabilities in the Face of Information and Communication Technologies in Spain]. Madrid. http://www.cermi.es/es-

ES/Biblioteca/Lists/Publicaciones/Attachments/36/Estudio20DiscapacidadTICFundA una.pdf.

Gutiérrez, P., and A. Martorell. 2011. "People with Intellectual Disability and ICTs". Comunicar 18 (36): 173-80. doi: 10.3916/C36-2011-03-09.

Inclusion International. 1996. Inclusion: News from Inclusion International. Brussels: Inclusion International. 
Jenaro, C., N. Flores, M. Cruz, M. C. Pérez, V. Vega, and V. A. Torres. 2018. "Internet and Cell Phone Usage Patterns among Young Adults with Intellectual Disabilities". Journal of Applied Research in Intellectual Disabilities 31 (2): 259-72. doi: 10.1111/jar.12388.

Jenaro, C., N. Flores, V. Vega, M. Cruz, M. C. Pérez, and V. A. Torres. 2018. “Cyberbullying among Adults with Intellectual Disabilities: Some Preliminary Data”. Research in Developmental Disabilities 72 (January): 265-74. doi: 10.1016/j.ridd.2017.12.006.

Kalmus, V. 2013. "Making Sense of the Social Mediation of Children's Internet Use: Perspectives for Interdisciplinary and Cross-Cultural Research". In Medienwelten im Wandel [Media Worlds in Change], edited by C. W. Wijnen, S. Trültzsch, and C. Ortner, 137-49. Wiesbaden: Springer. doi: 10.1007/978-3-531-19049-5_11.

Kalmus, V., C. von Feilitzen, and A. Siibak. 2012. 'Effectiveness of Teachers' and Peers' Mediation in Supporting Opportunities and Reducing Risks Online”. In Children, Risk and Safety on the Internet, edited by S. Livingstone, L. Haddon, and A. Görzig, 24556. Bristol: Policy Press.

Karaseva, A., A. Siibak, and P. Pruulmann-Vengerfeldt. 2015. "Relationships between Teachers`Pedagogical Beliefs, Subject Cultures, and Mediation Practices of Students' Use of Digital Technology". Cyberpsychology: Journal of Psychosocial Research on Cyberspace 9 (1): article 6. doi: 10.5817/CP2015-1-6.

Kydland, F., J. Molka-Danielsen, and S. Balandin. 2012. "Examining the Use of Social Media Tool "Flickr" for Impact on Loneliness for People with Intellectual Disability". In NOKOBIT 2012: Proceedings of the 2012 Norsk Konferanse for Organisasjoners 
Bruk Av Informasjonsteknologi, edited by T. Fallmyr, 253.264. Trondheim, Norway: Akademika forlag. http://dro.deakin.edu.au/view/DU:30062177.

Lawshe, C H. 1975. “A Quantitative Approach to Content Validity”. Personnel Psychology 28: 563-75. doi: 10.1111/j.1744-6570.1975.tb01393.x.

Livingstone, S., L. Haddon, A. Görzig, and K. Ólafsson. 2011. Risks and Safety on the Internet: The Perspective of European Children. Full Findings. London: EU Kids Online.

Lough, E., and M. H. Fisher. 2016. "Internet Use and Online Safety in Adults with Williams Syndrome”. Journal of Intellectual Disability Research 60 (10): 1020-30. doi: $10.1111 /$ jir.12281.

Luckasson, R., S. Bornthwick-Duffy, W. Buntinx, D. L. Coulter, E. M. Craig, A. Reeve, R. L. Schalock, et al. 2002. Mental Retardation. Definition, Classification and Systems Of Supports. Washington, DC: American Association on Mental Retardation.

McConkey, R., and M. Smyth. 2003. "Parental Perceptions of Risks with Older Teenagers Who Have Severe Learning Difficulties Contrasted with the Young People's Views and Experiences". Children \& Society 17 (1): 18-31. doi: 10.1002/chi.725.

Molin, M., E. Sorbring, and L. Löfgren-Martenson. 2015. “Teachers' and Parents' Views on the Internet and Social Media Usage by Pupils with Intellectual Disabilities". Journal of Intellectual Disabilities 19 (1): 22-33. doi: 10.1177/1744629514563558.

Morin, D., M. Rivard, A. G. Crocker, C. P. Boursier, and J. Caron. 2013. "Public Attitudes towards Intellectual Disability: A Multidimensional Perspective". Journal of Intellectual Disability Research 57 (3): 279-92. doi: 10.1111/jir.12008.

Munby, H. 1982. “The Place of Teachers' Beliefs in Research on Teacher Thinking and 
Decision Making, and an Alternative Methodology". Instructional Science 11 (3): 201-25. doi: $10.2307 / 23368318$.

Näslund, R., and Å. Gardelli. 2013. “'I Know, I Can, I Will Try’: Youths and Adults with Intellectual Disabilities in Sweden Using Information and Communication Technology in Their Everyday Life”. Disability \& Society 28 (1): 28-40. doi: 10.1080/09687599.2012.695528.

Normand, C. L., and F. Sallafranque-St-Louis. 2016. "Cybervictimization of Young People With an Intellectual or Developmental Disability: Risks Specific to Sexual Solicitation”. Journal of Applied Research in Intellectual Disabilities 29 (2): 99-110. doi: $10.1111 /$ jar.12163.

O’Brien, J. 1985. "Dignificación de las personas e integración en la comunidad en los programas de atención" [Dignification of People and Integration in the Community in Care Programs]. Siglo Cero. Revista Española Sobre Discapacidad Intelectual 102: $51-60$.

Palmer, S. B., M. L. Wehmeyer, D. K. Davies, and S. E. Stock. 2012. "Family Members' Reports of the Technology Use of Family Members with Intellectual and Developmental Disabilities". Journal of Intellectual Disability Research 56 (4): 40214. doi: $10.1111 / \mathrm{j} .1365-2788.2011 .01489 . x$.

Plichta, P. 2015. "Prevalence of Cyberbullying and Other Forms of Online Aggression among Polish Students with Mild Intellectual Disability”. E-Methodology 2: 112-27. doi: 10.15503/emet2015.112.127.

Sallafranque-St-Louis, F., and C. L. Normand. 2017. "From Solitude to Solicitation: How People with Intellectual Disability or Autism Spectrum Disorder Use the Internet”. 
Cyberpsychology: Journal of Psychosocial Research on Cyberspace 11 (1): article 7. doi: 10.5817/CP2017-1-7.

Seale, J. 2014. "The Role of Supporters in Facilitating the Use of Technologies by Adolescents and Adults with Learning Disabilities: A Place for Positive Risk-Taking”. European Journal of Special Needs Education 29 (2): 220-36. doi: 10.1080/08856257.2014.906980.

Seale, J., and D. Chadwick. 2017. "How Does Risk Mediate the Ability of Adolescents and Adults with Intellectual and Developmental Disabilities to Live a Normal Life by Using the Internet?" Cyberpsychology: Journal of Psychosocial Research on Cyberspace 11 (1): article 2. doi: 10.5817/CP2017-1-2.

Seale, J., M. Nind, and B. Simmons. 2013. "Transforming Positive Risk-Taking Practices: The Possibilities of Creativity and Resilience in Learning Disability Contexts". Scandinavian Journal of Disability Research 15 (3): 233-48. doi: 10.1080/15017419.2012.703967.

United Nations. 2006. Convention on the Rights of Persons with Disabilities. New York: Author.

Valero, M. A., L. Vadillo, R. Herradón, A. B. Bermejo, and R. Conde. 2011. Investigación sobre las tecnologías de la sociedad de la información para todos [Research on Information Society Technologies for All]. Madrid: CENTAC.

Wright, M. F. 2017. "Cyber Victimization and Depression Among Adolescents With Intellectual Disabilities and Developmental Disorders: The Moderation of Perceived Social Support”. Journal of Mental Health Research in Intellectual Disabilities 10 (2): 126-43. doi: 10.1080/19315864.2016.1271486. 
Table 1. Teachers' knowledge about online behaviour experienced or engaged in by students with intellectual disability

\begin{tabular}{|c|c|c|c|c|c|c|c|}
\hline \multirow[b]{2}{*}{ Online behaviour } & \multicolumn{2}{|c|}{ Experienced } & \multicolumn{2}{|c|}{ Engaged In } & \multicolumn{2}{|c|}{ Unknown } & \multirow{2}{*}{$\begin{array}{c}\text { Cochran's } \\
\text { Q }\end{array}$} \\
\hline & $n$ & $\%$ & $n$ & $\%$ & $n$ & $\%$ & \\
\hline Online bullying & 70 & $27.1^{\dagger \dagger}$ & 39 & $15.1^{\dagger \dagger} \cdot$ & 137 & 53.1 & $70.346^{*}$ \\
\hline Contact by/with strangers & 54 & 20.9 & 53 & 20.5 & 128 & $49.6^{\dagger \cdot \bullet}$ & $51.398^{*}$ \\
\hline $\begin{array}{l}\text { Sending/receiving inappropriate } \\
\text { and offensive pornographic } \\
\text { content }\end{array}$ & 38 & $14.7^{\dagger \dagger}$ & 31 & $12.0^{\dagger \dagger \dagger}$ & 163 & 63.2 & $154.664^{*}$ \\
\hline $\begin{array}{l}\text { Sending/receiving inappropriate } \\
\text { material about drugs }\end{array}$ & 10 & 3.9 & 3 & 1.2 & 200 & $77.5^{\dagger \dagger}$ & $355.251^{*}$ \\
\hline $\begin{array}{l}\text { Sending/receiving material } \\
\text { encouraging antisocial behaviour }\end{array}$ & 21 & 8.1 & 20 & 7.8 & 180 & $69.8^{\dagger \dagger}$ & $240.009^{*}$ \\
\hline Requesting personal information & 51 & 19.8 & 41 & 15.9 & 138 & 53.5 & $80.178^{*}$ \\
\hline $\begin{array}{l}\text { In-person meetings with people } \\
\text { met online }\end{array}$ & 28 & 10.9 & 27 & 10.5 & 170 & $65.9^{\dagger \dagger \dagger}$ & $189.785^{*}$ \\
\hline Threatening & 61 & $23.6^{\dagger \dagger}$ & 41 & $15.9^{\dagger \dagger}$ & 143 & 55.4 & $81.907^{*}$ \\
\hline $\begin{array}{l}\text { Sending/receiving violent o gore } \\
\text { content }\end{array}$ & 17 & $6.6^{\dagger}$ & 15 & $5.8^{\dagger \dagger} \cdot$ & 187 & 72.5 & $278.514^{*}$ \\
\hline Frauds or scams & 11 & 4.3 & 5 & 1.9 & 195 & $75.6^{\dagger \dagger \dagger}$ & $333.295^{*}$ \\
\hline $\begin{array}{l}\text { Harassment with a clear sexual } \\
\text { intention (grooming) }\end{array}$ & 22 & 8.5 & 9 & 3.5 & 189 & $73.3^{\dagger \bullet}$ & $286.531^{*}$ \\
\hline Participating in online gambling & 3 & 1.2 & 9 & 3.5 & 199 & $77.1^{\dagger \dagger}$ & $355.010^{*}$ \\
\hline $\begin{array}{l}\text { Illegal downloads or copyright } \\
\text { infringement }\end{array}$ & 14 & 5.4 & 41 & 15.9 & 162 & $62.8^{\dagger \dagger \cdot}$ & $175.821^{*}$ \\
\hline Misuse of personal data & 22 & 8.5 & 32 & 12.4 & 164 & $63.6^{\dagger}$ & $179.467^{*}$ \\
\hline Illegal access to online accounts & 7 & 2.7 & 6 & 2.3 & 200 & $77.5^{\dagger \dagger \dagger}$ & $354.910^{*}$ \\
\hline
\end{tabular}


Table 2. Information and Training Sources on Internet use and safety received and wanted

\begin{tabular}{|c|c|c|c|c|c|}
\hline \multirow[b]{2}{*}{ Source } & \multicolumn{2}{|c|}{ Received } & \multicolumn{2}{|c|}{ Wanted } & \multirow[b]{2}{*}{$\chi^{2}(1)$} \\
\hline & $n$ & $\%$ & $n$ & $\%$ & \\
\hline Workplace & 98 & $38.0^{\dagger \dagger}$ & 100 & $38.8^{\dagger \dagger}$ & 0.005 \\
\hline Training and Resource Centres for Teaching (CEFIRE) & 62 & 24.0 & 139 & $53.9^{\dagger}$ & $30.561^{*}$ \\
\hline Media & 106 & 41.1 & 42 & 16.3 & $27.562^{*}$ \\
\hline Internet service providers & 11 & 4.3 & 58 & 22.5 & $30.667^{*}$ \\
\hline Public Administration & 51 & $19.8^{\dagger}$ & 104 & $40.3^{\circ}$ & $18.395^{*}$ \\
\hline Non-profit organizations & 49 & 19.0 & 62 & 24.0 & 1.371 \\
\hline Specialized websites & 58 & $22.5^{\circ}$ & 56 & 21.7 & 0.009 \\
\hline Family and friends & 74 & 28.7 & 24 & 9.3 & $24.500^{*}$ \\
\hline Other sources (e.g. police, self-taught) & 19 & $7.4^{\circ}$ & 10 & $3.9^{\circ}$ & 3.048 \\
\hline Have not received or wanted to receive information & 1 & 0.4 & 2 & 0.8 & 0.000 \\
\hline
\end{tabular}

Chi-square significant at ${ }^{\dagger} p<.05,{ }^{\dagger \dagger} p<.01$ for teaching position

Chi-square significant at ${ }^{*} p<.05,{ }^{\circ} p<.01$ for teaching level

McNemar's test significant at ${ }^{*} p<.001$ 
Table 3. Internet risk mediation strategies implemented and/or promoted by teachers

\begin{tabular}{|c|c|c|c|c|c|c|c|c|c|c|c|c|}
\hline \multirow[b]{3}{*}{ Strategy } & \multirow{2}{*}{\multicolumn{2}{|c|}{$\begin{array}{c}\text { Total } \\
\text { sample }\end{array}$}} & \multicolumn{5}{|c|}{ Teaching position } & \multicolumn{5}{|c|}{ Teaching level } \\
\hline & & & \multicolumn{2}{|c|}{ GEd } & \multicolumn{2}{|c|}{ SEd } & \multirow[b]{2}{*}{$\chi^{2}$} & \multicolumn{2}{|c|}{ PET } & \multicolumn{2}{|c|}{ SET } & \multirow[b]{2}{*}{$\chi^{2}$} \\
\hline & $n$ & $\%$ & $n$ & $\%$ & $n$ & $\%$ & & $n$ & $\%$ & $n$ & $\%$ & \\
\hline Talks/workshops aimed at families & 131 & 51.2 & 90 & 62.9 & 41 & 36.3 & $16.896^{* * * *}$ & 81 & 47.6 & 50 & 58.1 & 2.516 \\
\hline Talks/workshops aimed at the students with ID & 97 & 37.9 & 45 & 31.5 & 52 & 46.0 & $5.076^{*}$ & 66 & 38.8 & 31 & 36 & 0.088 \\
\hline Talk about what they do online & 215 & 84.0 & 116 & 81.1 & 99 & 87.6 & 1.524 & 143 & 84.1 & 72 & 83.7 & 0.000 \\
\hline Sit next to them while using the Internet & 123 & 48.0 & 55 & 38.5 & 68 & 60.2 & $11.070^{* *}$ & 90 & 52.9 & 33 & 38.4 & $4.290^{*}$ \\
\hline Stay close to them when using the Internet & 172 & 67.2 & 83 & 58 & 89 & 78.8 & $11.369^{* *}$ & 121 & 71.2 & 51 & 59.3 & 3.134 \\
\hline Share online activities & 160 & 62.5 & 79 & 55.2 & 81 & 71.7 & $6.592^{*}$ & 111 & 65.3 & 49 & 57.0 & 1.349 \\
\hline Activate content control filters & 134 & 52.3 & 82 & 57.3 & 52 & 46.0 & 2.807 & 82 & 48.2 & 52 & 60.5 & 2.952 \\
\hline Install navigation and access control programs & 102 & 39.8 & 71 & 49.7 & 31 & 27.4 & $12.088^{* *}$ & 54 & 31.8 & 48 & 55.8 & $12.796^{* * *}$ \\
\hline Install antivirus or anti-spam programs & 120 & 46.9 & 66 & 46.2 & 54 & 47.8 & 0.018 & 77 & 45.3 & 43 & 50.0 & 0.336 \\
\hline Prohibit them from using social networking sites & 65 & 25.4 & 36 & 25.2 & 29 & 25.7 & 0.000 & 42 & 24.7 & 23 & 26.7 & 0.041 \\
\hline Control the use of social networking sites & 68 & 26.6 & 36 & 25.2 & 32 & 28.3 & 0.179 & 43 & 25.3 & 25 & 29.1 & 0.246 \\
\hline Prohibit them from sharing personal information & 56 & 21.9 & 24 & 16.8 & 32 & 28.3 & $4.263^{*}$ & 40 & 23.5 & 16 & 18.6 & 0.548 \\
\hline Talk about which sites are appropriate & 140 & 54.7 & 73 & 51.0 & 67 & 59.3 & 1.414 & 90 & 52.9 & 50 & 58.1 & 0.431 \\
\hline Talk about misleading advertising online & 144 & 56.5 & 79 & 55.2 & 65 & 58.0 & 0.102 & 88 & 52.1 & 56 & 65.1 & 3.433 \\
\hline Talk about the risks of data / identity theft & 144 & 56.5 & 85 & 59.4 & 59 & 52.7 & 0.909 & 82 & 48.5 & 62 & 72.1 & $11.943^{* *}$ \\
\hline $\begin{array}{l}\text { Talk about the risks of online chatting or flirting } \\
\text { with strangers }\end{array}$ & 165 & 64.5 & 87 & 60.8 & 78 & 69.0 & 1.507 & 103 & 60.6 & 62 & 72.1 & 2.816 \\
\hline $\begin{array}{l}\text { Talk about what they would do if they were worried } \\
\text { about something that had happened online }\end{array}$ & 118 & 46.1 & 60 & 42.0 & 58 & 51.3 & 1.869 & 74 & 43.5 & 44 & 51.2 & 1.050 \\
\hline Control time on the Internet & 104 & 40.6 & 52 & 36.4 & 52 & 46.0 & 2.055 & 74 & 43.5 & 30 & 34.9 & 1.429 \\
\hline Check their browsing history & 45 & 17.6 & 19 & 13.3 & 26 & 23.0 & 3.474 & 33 & 19.4 & 12 & 14.0 & 0.828 \\
\hline Check their messages & 39 & 15.2 & 16 & 11.2 & 23 & 20.4 & 3.427 & 27 & 15.9 & 12 & 14.0 & 0.049 \\
\hline $\begin{array}{l}\text { Check friendships or contacts added to their social } \\
\text { media profile }\end{array}$ & 35 & 13.7 & 19 & 13.3 & 16 & 14.2 & 0.000 & 23 & 13.5 & 12 & 14.0 & 0.000 \\
\hline Place fixed devices in common areas & 49 & 19.1 & 32 & 22.4 & 17 & 15.0 & 1.745 & 28 & 16.5 & 21 & 24.4 & 1.846 \\
\hline $\begin{array}{l}\text { Allow them to use mobile devices only in common } \\
\text { areas }\end{array}$ & 77 & 30.1 & 43 & 30.1 & 34 & 30.1 & .000 & 48 & 28.2 & 29 & 33.7 & .577 \\
\hline Other (disable wifi password, firewall) & 25 & 9.8 & 15 & 10.5 & 10 & 8.8 & 0.051 & 18 & 10.6 & 7 & 8.1 & 0.160 \\
\hline Not used any strategy & 1 & 0.4 & 0 & 0.0 & 1 & 0.9 & 0.013 & 1 & 0.6 & 0 & 0.0 & 0.000 \\
\hline
\end{tabular}

GEd: general education teacher; SEd: special education teacher; PET: Primary Education Teacher; SET: Secondary education teacher Chi-square significant at ${ }^{*} p<.05,{ }^{* *} p<.01,{ }^{* * *} p<.001$ 